\title{
PENGARUH WATAK GENETIK DAN RIWAYAT TRAUMATIK TERHADAP TINGKAT PENGENDALIAN AMARAH DAN KEMAMPUAN MEMAAFKAN
}

\author{
Kasyadi \\ Program Pasca Sarjana \\ Universitas Muhammadiyah Yogyakarta \\ E-mail: kasyadismkmuh1sleman@gmail.com
}

\begin{abstract}
Abstrak
Penelitian ini bertujuan untuk mengetahui pengaruh; (1) watak genetic terhadap pengendalian amarah, (2) watak genetic terhadap kemampuan memaafkan, (3) riwayat traumatic terhadap tingkat pengendalian amarah, (4) riwayat traumatic terhadap kemampuan memaafkan, (5) antara watak genetic bersama-sama dengan riwayat traumatic terhadap tingkat pengendalian amarah, dam (6) antara watak genetic bersama-sama dengan riwayat traumatic terhadap kemampuan memaafkan.Penelitian ini menggunakan metode deskriptif kuantitatif dengan subjek siswa.Hasil penelitian menunjukkan (1) ada pengaruh positif dan signifikan antara watak genetic dengan tingkat pengendalian amarah dengan nilai koefisien regresi (b1) sebesar 0,466. (2) Ada pengaruh positif dan signifikan antara watak genetic dengan kemampuan memaafkan dengan nilai koefisien regresi (b1) sebesar 0,347. (3) Tidak ada pengaruh signifikan antara riwayat traumatic dengan tingkat pengendalian amarah dengan nilai koefisien regresi (b1) sebesar 0,815 . (4) Ada pengaruh positif dan signifikan antara riwayat traumatic dengan kemampuan memaafkan dengan nilai koefisien regresi (b1) sebesar 0,000. (5) Ada pengaruh yang positif dan signifikan antara watak genetic bersama-sama dengan riwayat traumatic terhadap tingkat pengendalian amarah dengan nilai Fhitung sebesar 13,812 dengan nilai signifikansi $\mathrm{F}$ sebesar 0,000. (6) Ada pengaruh positif dan signifikan antara watak genetic bersama-sama dengan riwayat traumatic terhadap kemampuan memaafkan dengan nilai Fhitung sebesar 14,637.
\end{abstract}

Kata kunci: watak genetic, riwayat traumatic, pengendalian amarah, dan kemampuan memaafkan

\begin{abstract}
This study aims to determine the effect; (1) genetic character to anger control, (2) genetic character to forgiveness ability, (3) traumatic history of anger control rates, (4) traumatic history of forgiveness, (5) between genetic traits together with traumatic history of the level of anger control, and (6) between genetic traits together with traumatic history of forgiveness. This study uses descriptive quantitative methods with student subjects. The results of the study show (1) there is a positive and significant influence between genetic character and the level of anger control with a regression coefficient (b1) of 0.466. (2) There is a positive and significant influence between genetic character and the ability to forgive with a regression coefficient (b1) of 0.347. (3) There is no significant influence between traumatic history and the level of anger control with a regression coefficient (b1) of -0.815. (4) There is a positive and significant influence between traumatic history and forgiveness with a regression coefficient (b1) of 0,000. (5) There is a positive and significant influence between genetic traits together with traumatic history on the level of anger control with a calculated $F$ value of 13,812 with a significance value of $F$ of 0,000. (6) There is a positive and significant influence between genetic traits together with traumatic history of forgiveness with a calculated $F$ value of 14,637.
\end{abstract}

Keywords: genetic character, traumatic history, anger control, and forgiveness ability

\section{Info Artikel}

Diterima Januari 2019, disetujui Februari 2019, diterbitkan Juni 2019 


\section{PENDAHULUAN}

Usaha pemerintah Indonesia dalam membentuk watak generasi bangsa yang beradab sudah tertuang dalam undang-undang. Undang-Undang No. 20 Tahun 2003 tentang Sistem Pendidikan Nasional mengamanatkan pembentukan karakter memalui pendidikan, dan Undang-Undang No. 17 Tahun 2007 tentang Rencana Jangka Panjang (RPJP) Nasional bermisi mewujudkan masyarakat berkahlak mulia, bermoral, beretika, berbudaya, dan beradab berdasarkan falsafah pancasila. Usaha itu terlihat belum membuahkan hasil yang baik karena menurut rilis Kemendagri jumlah konflik sosial tiga tahun terakhir mencapai 201. Terdiri dari 92 konflik tahun 2013, 83 konflik tahun 2014, dan 26 konflik tahun 2016. Bentuk konflik bermacam-macam seperti; bentrok antarwarga, isu sara, kesenjangan sosial, institusi pendidikan, sengketa lahan, dan eksespolitik.

Sedangkan menurut data Komisi Perlindungan Anak Indonesia (KPAI), sepanjang tahun 2013 telah terjadi 255 kasus kekerasan yang menelan korban jiwa 20 siswa di seluruh Indonesia. Jumlah ini hampir dua kali lipat lebih banyak dari tahun 2012 yang mencapai 147 kasus dengan jumlah meninggal 17 siswa. Tahun 2014 lalu, KPAI sudah menerima 2.737 kasus atau 210 setiap bulannya termasuk kasus kekerasan dengan pelaku anak-anak yang ternyata naik hingga 10 persen. KPAI bahkan memprediksi tahun 2015 angka kekerasan dengan pelaku anak-anak, termasuk tawuran antar siswa akan meningkat sekitar 12-18 persen.

Beberapa daerah, tahun 2013 sedikitnya terdapat 255 kasus tawuran di Jakarta dengan jumlah siswa yang meninggal mencapai 20 orang. Jumlah ini meningkat dari tahun sebelumnya yang hanya terdapat 128 kasus tawuran dengan korban mencapai 17 orang. Tidak saja di Jakarta, tawuran juga terjadi di Yogyakarta. Dalam kurun waktu tahun 2011-2013 tercatat 13 kasus di kota dan kabupaten Yogyakarta. Belum lama ini di ujung tahun 2016, kota Yogyakarta sempat digegerkan dengan terbunuhnya seorang pelajar yang ditusuk oleh pelajar lain ketika perjalanan pulang dari obyek wisata.

Khusus Kabupaten Sleman, tidak saja permasalahan tawuran, akan tetapi ada fenomena yang disebut klitih. Di kalangan masyarakat, klitih dipahami sebagai tindakan untuk melumpuhkan siapapun dengan cara kekerasan fisik. Seperti kejadian pada akhir tahun 2014, Dhimas Afrizal Mustofa, siswa SMK Negeri di Sayegan Sleman meninggal terkena klitih. Siswa tersebut dianiaya oleh 16 siswa yang berasal dari SMA Negeri di 
Sleman. Para pelaku tidak mengenal korban. Pelaku melakukannya secara spontan saat korban melintas dari arah berlawanan. Pertengahan tahun 2015, Tatag Riyanto, siswa SMK Suwastadi Sleman dilempari batu oleh pengendara motor yang mengenakan seragam SMA/SMK di jalan Turi Kabupaten Sleman. Siswa mengalami luka memar pada kaki, luka-luka pada tangan, dan sempat tidak bisa sekolah selama satu minggu. Kasus korban klitih terbaru terjadi pada 29 Agustus 2015 di kawasan Kecamatan Turi Kabupaten Sleman. Korbannya anak SMA Negeri di Turi. Ia mengalami retak tulang akibat dipukuli dan ditendang oleh orang yang tidak dikenal dengan mengenakan seragam sekolah.

Bermacam persoalan sosial di atas, jika dilihat dari kebijakan pemerintah untuk mensukseskan amanah Undang-Undang No. 20 Tahun 2003 dan No. 17 Tahun 2007 ternyata belum menyentuh aspek orang tua selaku pendidik pertama anak dalam keluarga. Selama ini pemerintah baru membuat program yang terkait dengan pembatasan tingkat kelahiran anak. Oleh sebab itu, diperlukan program dari pemerintah melalui lembaga pernikahan berupa penyuluhan pra-nikah dan pasca-nikah agar keluarga berfungsi secara maksimal.

Keluarga sebagai lembaga terkecil dalam struktur masyarakat memiliki peran besar membentuk anak sebagai generasi penerus bangsa. Sebab menurut Ibn Qayyim orang tua mewariskan karakter pada anaknya melalui gen (Hasan, 2008). Selain itu, pola asuh orang tua dan kehidupan keluarga yang kurang baik dapat yang dapat memicu trauma, sehingga tatkala anak tumbuh besar dan berinteraksi dengan lingkungan sosialnya sulit untuk mengelola sekaligus mengendalikan emosi saat mengalami segala sesuatu yang tidak menyenangkan.

Lemahnya kemampuan dalam mengelola emosi menurut Nuri Aprilia dan Herdina Indrijati dalam penelitiannya dapat memicu tawuran (Aprilia, 2014). Pribadi pemarah muncul karena memiliki riwayat trauma hubungan dalam keluarga yang kurang lekat. Sebagaimana pendapat Cahyani dkk., yang mengungkapkan semakin lekat hubungan anak dengan keluarga dapat mengurangi tingkat kemarahan dan perilaku agresif (Cahyani dkk, 1999).

Setiap orang berbeda-beda dalam mengekpresikan kemarahannya. Perbedaan tersebut tergantung dari pola perkembangan kepribadian masing-masing individu. Bagi yang mengalami perkembangan kepribadian yang baik, memiliki kelambatan dalam 
marah tetapi cepat reda. Sebaliknya, bagi yang tidak baik, cepat marah dan lambat redanya. Dalam Islam, menahan amarah dan perintah untuk tidak marah sesuatu yang dianjurkan.

Selain perintah untuk menahan amarah, dalam Islam ada perintah untuk memaafkan kesalahan orang yang melakukan kekerasan secara fisik maupun nonfisik.Dengan memaafkan, berarti sudah memutus untuk tidak menghukum atas ketidakadilan yang diterima. Butuh kemampuan untuk bisa memaafkan. Kemampuan tersebut bisa berupa upaya untuk merasakan perasaan atau pengalaman orang lain serta sejauh mana komitmen dalam membangun hubungan sosial.

Bermacam sikap dan perilaku anak yang terbentuk dari berbagai macam keluarga berkumpul dalam satu lingkungan sekolah. Bagi sekolah yang memiliki standard pengelolaan, sumberdaya yang baik, serta fasilitas memadahi, tentu akan cepat merespon segala sesuatu sesuai dengan tingkat permasalahan yang muncul. Gambaran tentang apa yang seharusnya terjadi dan kenyataan yang terjadi di masyarakat seperti terurai di atas menjadi dasar penelitian ini dilakukan. Adapun fokus penelitiannya pada Pengaruh Watak Genetik dan Riwayat Traumatik Terhadap Tingkat Pengendalian Amarah dan Kemampuan Memaafkan dengan fokus untuk mengetahuipengaruh antara watak genetic dengan tingkat pengendalian amarah? Pengaruh antara watak genetic dengan kemampuan memaafkan? Pengaruh antara riwayat traumatic dengan tingkat pengendalian amarah? Pengaruh antara riwayat traumatic dengan kemampuan memaafkan? Pengaruh antara watak genetic bersama-sama dengan riwayat traumatic terhadap tingkat pengendalian amarah?

\section{Watak Genetik}

Menurut Sujianto, watak adalah pribadi jiwa yang menyatakan dirinya dalam segala tindakan dan pernyataan dalam hubungannya dengan bakat, pendidikan, pengalaman, dan alam sekitar (Sujianto, 1991). Menurut Pertiwi dkk, watak adalah sifat batin manusia yang mendorong perilaku yang dilakukan dan terbentuk oleh pengaruh dari dalam dan dari luar (Pertiwi dkk, 2013). Berdasar definisi tersebut dapat disimpulkan bahwa watak adalah pendorong manusia untuk melakukan dan menyatakan sesuatu.Watak dapat berubah, karena itu ia dapat dipengaruhi, diperbaiki, dan dimajukan. Ilmu watak dalam bahasa asing sering disebut karakterologie. Istilah 
karakterologie merupakan istilah belanda yang berasal dari kata karakter, yang berarti watak, dan logos yang berarti ilmu. Sehingga, karakterologie ketika diistilahkan kedalam bahasa Indonesia menjadi ilmu watak.

Genetika, atau genetik, adalah ilmu yang membahas tentang pewarisan sifat-sifat induk kepada turunannya. Pada mulanya, ilmu ini berkembang berupa genetika empiris, yakni genetika yang didasarkan atas pengalaman sehari-hari atau observasi yang dilakukan oleh pemerhati secara tidak sistematis (Citrawati, 2014).

Faktor keturunan merupakan salah satu factor penting yang mempengaruhi perkembangan intelektual dan kepribadian. Bahkan, karakteristik seseorang dipengaruhi oleh gen yang merupakan karakteristik bawaan yang diwariskan dari orang tuanya, yang akan terlihat sebagai karakteristik yang dapat diobservasi atau diukur (Hasan, 2006).Kajian psikologi tentang orang tua yang menurunkan sifat temperamen, stabilitas emosi dan kemampuan tertentu kepada anaknya sudah lama dilakukan oleh para ahli genetika. Prosesnya, kromosom dalam tubuh orang tua pindah ke anak. Sebagaian besar sel tubuh berisi 46 kromosom. Pada masa pertumbuhan, manusia menerima 23 kromosom dari sperma ayah dan 23 pasang ovum dari ibu (Atkinso, 1983).

\section{Riwayat Traumatik}

Trauma dapat diartikan sebagai kerusakan atau luka yang disebabkan oleh tindakan-tindakan fisik dengan terputusnya kontinuitas normal suatu struktur (Dorland, 2002). Menurut kamus psikologi yang diterbitkan tim widyatamma, trauma adalah luka berat pengalaman yang menyebabkan organisme menderita kerusakan fisika maupun psikologis (Tim Widyatamma, 2010).

Menurut Herman, trauma psikologis anak merupakan ancaman fisik atau psikologis yang berupa penyerangan fisi, identitas diri, integritas, keselamatan maupun kelangsungan hidup anak. American Psychiatric Associantion mendefinisikan trauma psikologi sebagai suatu peristiwa yang dapat mendatangkan bahaya dan menyebabkan kematian kepada diri sendiri maupun orang lain dan memunculkan perasaan ketakutan, tidak berdaya. Menurut Kira, peristiwa traumatis merupakan peristiwa yang dapat bersifat subjektif mendatangkan perasaan tidak berdaya dan distress bagi pihak yang mengalami maupun yang menyaksiskan. Dari jumlah kejadiannya menurut Lenore Terr, trauma terjadi hanya sekali (single trauma), dan trauma terjadi berulang kali (repeated 
trauma). Wittchen et al. menambahkan, peristiwa traumatis dapat berupa trauma berkelanjutan (continuous trauma). Sementara itu, dari intense terjadinya dapat dibagi menjadi; peristiwa yang disengaja oleh manusia, peritiwa yang tidak disengaja oleh manusia, dan bencana alam (Charles, 2012).

NCTSN(National Children Trauma Stress Network) tahun 2000 (Pitaloka, 2012), mempublikasian hasil temuannya yang terkait faktor penyebab trauma psikologis, antara lain:kekerasan komunitas, komplek trauma, trauma dalam kekerasan rumah tangga, trauma masa kecil, trauma pengobatan,bencana alam, pengabaian anak, kekerasan fisik, trauma perang dan pengungsian, kekerasan di sekolah, pelecehan seksual, trauma terorisme, dan terakhir trauma duka cita.

\section{Marah}

Menurut Purwanto dan Mulyono, marah berarti perubahan internal atau emosional yang menimbulkan penyerangandan penyiksaan guna mengobati apa yang ada dalam hati (Purwanto, 2015). Al-Jurjani menjelaskan marah adalah perbuatan yang terjadi pada waktu mendidihnya darah di dalam hati untuk memperoleh kepuasan apa yang terdapat di dalam dada. Sedangkan menurut Gakfar, marah merupakan sublimasi perasaan terhadap lingkungan dan kekuatan yang terdapat di sekitarnya, dan bertujuan untuk mendapatkan ketenangan (Gakfar, 2015).

Menurut Hamzah, pada dasarnya seseorang yang sedang marah memiliki ciri-ciri sebagai berikut (Hamzah, 2015)

1. Wajah

Orang yang sedang marah cenderung mengalami perubahan warna kulit, seperti kuning pucat. Pada ujung-ujung jari bergetar keras, bola mata memerah, timbul buih pada sudut mulut, gerakan menjadi tidak terkendali, hidung kembang kempis, serta terjadi perubahan-perubahan fisik lainnya.

2. Lidah

Meluncurkan makian, kata-kata menyakitkan, celaan, dan ucapan-ucapan tidak baik yang tidak umum digunakan. Apabila itu digunakan orang umumnya merasa rishi mendengarnya. 
3. Anggota tubuh

Ada keinginan untuk merobek,melukai,memukul, bahkan membunuh. Jika amarah itu tidak terlampiaskan pada orang yang dimarahinya, kekesalannya akan berbalik kepada dirinya sendiri. Ia akan memukul tubuhnya, merobek-robek pakainnya sendiri, kadang kala memukul tangannya ke tanah, atau berulang kali ia akan jatuh pingsan karena kesal.

4. Hati

Ada rasa benci yang timbul dalam bentuk dendam dan dengki, menyembunyikan keburukandan merasa sedih atas kegembiraannya, merasa gembira dalam dukanya,memutuskan hubungan dan menjelek-jelekannya.

Menurut Nuh, ada beberapa ciri-ciri yang dapat dilihat apabila seseorang sedang marah, di antaranya;Membesarnya pembuluh darah dan urat leher disertai memerahnya wajah dan kedua mata, merengut dan mengerutnya wajah dan dahi, permusuhan kepada pihak lain melalui lisan, tangan, kaki, atau sarana lainnya, membalas permusuhan orang lain dengan permusuhan pula tanpa memperhitungkan akibat yang ditimbulkannya (Nuh dan Purwanto, 2015).

\section{Memaafkan}

Ada tiga konsep memaafkan terurai jelas oleh Michael E. McCullough dalam tulisannya berjudul "Forgiveness, Forbearance, and Time: The Temporal Unfolding of Transgression-Related Interpersonal Motivations". Pertama, memaafkan menurut Enright and Colleagues (e.g., Enright, Gassin, \& Wu, 1992) adalah penanggulangan dampak negatif dan keputusan kepada pelanggar, tidak dengan menyangkal diri, hak untuk mempengaruhi tersebut dan pengahakiman, tetapi dengan berusaha untuk melihat pelanggar dengan kasih saying, kebajikan, dan cinta. Kedua, memaafkan menurut Exline dan Baumeister (2000) adalah "pembatalan hutang" dengan orang yang telah terluka atau dirugikan. Dan ketiga, memaafkan menurut McCullough (1997) adalah satuan perubahan motivasi di mana seseorang menjadi (a) semakin menurun termotivasi untuk balas terhadap mitra hubungan yang menyakiti hatinya, (b) semakin menurun termotivasi untuk mempertahankan keterasingan dari perilaku, dan (c) semakin termotivasi oleh konsiliasi dan niaya baik untuk pelaku, meskipun tindakan menyakitkan pelaku. 
Hannah Arendt (1959), seorang Yahudi berkebangsaan Jerman. Memaafkan, menurutnya, adalah tindakan untuk memperbaiki dirinya sendiri maupun masyarakat atas tindakan-tindakan masa lalu yang memang tidak bisa berubah dan diprediksi demi masa depan yang lebih baik.Memaafkan juga berarti memutuskan untuk tidak meghukum atas ketidakadilan yang kita terima, yang kita tunjukkan dalam aksi nyata dan mengalami reaksi emosional yang hadir setelahnya (Affinito, 1999).

Berikut ini dijelaskan secara lebih rinci beberapa faktor yang memiliki pengaruh pemberian maaf antaralain; empati untuk andil merasakan perasaan orang lain, atribusi pelaku dan kesalahannya, tingkat kelukaan berpengaruh terhadap respon. Jika kelukaan hati mendalam maka sulit untuk memberi maaf. Sebaliknya, jika lukanya tidak mendalam dapat mudah memberi maaf, karakteristik kepribadian, dan kualitas hubungan.

Kecenderungan umum menyatakan genetic dapat mempengaruhi marah. Hal ini dapat dilihat dari kajian tentang genetic yang mengalami perkembangan yang dijadikan dasar perilaku genetik. Gen diuji lebih mendalam untuk melihat pengaruhnya terhadap perkembangan emosi anak. Kimberly J. Saudino, dalam artikerlnya berjudul "Behavioral Genetics and Child Temperament" menyatakan penemuan genetik pengaruh pada marah hanya langkah pertama dalam pemahaman tentang perbedaan individu dalam awal pengembangan kepribadian, karena factor lingkungan ternyata ikut menentukan besar dan tidaknya marah pada anak.

Selain gen, trauma pada anak dijadikan objek kajian penelitian untuk melihat pengaruhnya terhadap marah yang diekspresikan dalam bentuk kekerasan atau lainnya. Rahmaniar Nuringtyas Margaretha dan Rani Rachim menyatakan, secara empiris ada hubungan antara trauma kekerasan dalam rumah tangga (KDRT) masa kanak dengan keterlibatan dalam kekerasan dalam relasi intim, baik sebagai pelaku, maupun korban.

Dalam konteks Indonesia, secara khusus di Surabaya dan Sidoarjo, ditemukan bahwa pengalaman anak laki-laki yang menyaksikan dan mengalami KDRT berhubungan dengan perilaku kekerasan terhadap pasangannya kelak Anak-anak koban langsung dan korban saksi kekerasan dalam rumah tangga menjadi terbiasa hidup di dalam keluarga yang melakukan kekerasan, sehingga menurut mereka kekerasan merupakan hal yang biasa saja. Maka kekerasan dapat dianggap sebagai hal yang wajar untuk menyelesaikan sebuah konflik yang terjadi dalam suatu relasi intim. Pandangan 
lain terkait traumatic, Niko Sumadi menyatakan pengalaman traumatik pada hidup seseorang dan komunikasi keluarga tidak efektif bisa menyebabkan pembentukan pribadi penyimpangan seksual lesbian.

Penelitian yang menguji hubungan genetic terhadap sikap memaafkan secara spesifik belum pernah dilakukan. Namun, jika mengacu pada Kimberly J. Saudino yang berpendapat bahwa, genetic dapat mempengaruhi marah, tentunya genetic dapat pula mempengaruhi sikap memaafkan. Sebab, marah dan memaafkan adalah dua sifat yang berlainan. Sedangkan ilmuan yang fokus tentang kajian memaafkan salah satunya Michael E. McCullough yang berpendapat ada hubungan antara pelanggaran dengan kesabaran, kecenderungan memaafkan, dan pengampunan sementara.

Sebagaimana pada pendapat yang menyatakan ada pengaruh trauma terhadap marah, tentu ada pula pengaruh trauma terhadap maaf asalkan anak yang mengalami trauma memiliki tingkat religiusitas yang baik seperti yang dikemukakan Ahmad Muhammad Diponegoro dan Sutipyo Ru'iya bahwa meningkatkan pemaafan pada remaja, perlu peningkatan religiusitas dan peningkatan kesejahteraan subyektifnya.

Sebab, trauma sulit diperbaiki, terlebih sampai pada level dendam. Dan dendam kurang berkorelasi pada sikap memberi maaf. Selain dendam, seorang anak yang mengalami proses perceraian orang tua akan mengalami kesulitan untuk memberi maaf meskipun proses perceraian dilakukan dalam jangka waktu yang lama. Sebagaimana pendapat Mustika Dewi bahwa remaja yang mengalami perceraian orangtua dapat melihat makna positif dalam usaha mempertahankan. Dan ternyata lamanya proses perceraian tidak berkaitan dengan kemampuan seseorang dalam memaafkan.

\section{KESIMPULAN}

Berdasarkan data yang diperoleh dari hasil analisis yang dilakukan maka dapat ditarik kesimpulan sebagai berikut:

1. Terdapat pengaruh watak genetic dengan tingkat pengendalian amarah. Hal tersebut dapat ditunjukan dengan nilai koefisien regresi (b1) sebesar 0,466. Pada taraf signifikansi 5\%, dapat diketahui t hitung sebesar 2,825 dengan nilai signifikansi sebesar 0,006 karena koefisien regresi mempunyai nilai positif dan nilai signifikansi (p) < 0,05 maka dapat disimpulkan terdapat pengaruh positif dan signifikan watak genetik terhadap terhadap pengendalian amarah. 
2. Terdapat pengaruh watak genetic dengan kemampuan memaafkan.Hal tersebut dapat ditunjukan dengan nilai koefisien regresi (b1) sebesar 0,347. Pada taraf signifikansi 5\%, dapat diketahui t hitung sebesar 2,882 dengan nilai signifikansi sebesar 0,005 karena koefisien regresi mempunyai nilai positif dan nilai signifikansi (p) $<0,05$ maka dapat disimpulkan terdapat pengaruh positif dan signifikan watak genetik terhadap terhadap pengendalian amarah.

3. Tidak ada pengaruh riwayat traumatic dengan tingkat pengendalian amarah.Hal tersebut dapat ditunjukan dengan nilai koefisien regresi (b1) sebesar -0,815. Pada taraf signifikansi 5\%, dapat diketahui t hitung sebesar $-3,708$ dengan nilai signifikansi sebesar 0,000 karena koefisien regresi mempunyai nilai positif dan nilai signifikansi $(\mathrm{p})<0,05$ maka dapat disimpulkan tidak terdapat yang signifikan watak genetik terhadap terhadap pengendalian amarah.

4. Terdapat pengaruh riwayat traumatic dengan kemampuan memaafkan.Hal tersebut dapat ditunjukan dengan nilai koefisien regresi (b1) sebesar 0,000. Pada taraf signifikansi 5\%, dapat diketahui t hitung sebesar 0,002 dengan nilai signifikansi sebesar 0,998 karena koefisien regresi mempunyai nilai positif dan nilai signifikansi (p) < 0,05 maka dapat disimpulkan terdapat pengaruh positif dan signifikanriwayat traumatic dengan kemampuan memaafkan..

5. Terdapat pengaruh watak genetic bersama-sama dengan riwayat traumatic terhadap tingkat pengendalian amarah. Hal ini ditunjukan dengan nilai Fhitung sebesar 13,812 dengan nilai signifikansi $\mathrm{F}$ sebesar 0,000. Karena nilai signifikansi $\mathrm{F}<0,05$ maka terdapat pengaruh watak genetic bersama-sama dengan riwayat traumatic terhadap tingkat pengendalian amarah. Nilai koefisien determinasi (R2) sebesar 0,243 atau 24,3\%. Nilai koefisien determinasi tersebut menunjukkan 24,3\% pengendalian amarah dapat dijelaskan oleh variabel watak genetic dan riwayat traumatic sedangkan sisanya sebesar $75,7 \%$ dijelaskan oleh variabel lain yang tidak diteliti dalam penelitian ini.

6. Terdapat pengaruh watak genetic bersama-sama dengan riwayat traumatic terhadap kemampuan memaafkan. Hal ini ditunjukan dengan nilai Fhitung sebesar 14,637 dengan nilai signifikansi $\mathrm{F}$ sebesar 0,000 . Karena nilai signifikansi $\mathrm{F}<0,05$ maka terdapat pengaruh watak genetic bersama-sama dengan riwayat traumatic terhadap kemampuan memaafkan. Nilai koefisien determinasi (R2) sebesar 0,254 atau 25,4\%. 
Nilai koefisien determinasi tersebut menunjukkan 25,4\% kemampuan memaafkan dapat dijelaskan oleh variabel watak genetic dan riwayat traumatic sedangkan sisanya sebesar 74,6\% dijelaskan oleh variabel lain yang tidak diteliti dalam penelitian ini. Sumbangan efektif masing-masing variabel yaitu 10,2\% dengan sumbangan relative sebesar 39\%. Sedangkan variabel riwayat traumatic memberikan sumbangan efektif sebesar $16 \%$ dengan sumbangan relative $61 \%$. 